Saudi Journal of Business and Management Studies Abbreviated Key Title: Saudi J Bus Manag Stud ISSN 2415-6663 (Print) |ISSN 2415-6671 (Online) Scholars Middle East Publishers, Dubai, United Arab Emirates Journal homepage: http://scholarsmepub.com/sjbms/

Original Research Article

\title{
The Effectiveness and Strategy to Increase of Hotel and Restaurant Taxes
}

\author{
Apip Supriadi*
}

Economics Development Department, Economics Faculty, Siliwangi University, Jl. Siliwangi No.24, Kahuripan, Kec. Tawang, Tasikmalaya, Jawa Barat 46115, Indonesia

DOI: 10.36348/SJBMS.2019.v04i09.006

| Received: 20.08.2019 | Accepted: 27.08.2019 | Published: 30.09.2019

*Corresponding author: Apip Supriadi

\section{Abstract}

This study aims to determine the effectiveness of hotel and restaurant taxes and hotel and restaurant tax increase strategies. The research method used a survey method. The population was 341 taxpayers with a sample of 103 taxpayers in Tasikmalaya City. The analytical tool used is effectiveness analysis and SWOT analysis. The results showed that the effectiveness of hotel and restaurant tax included in the criteria is very effective. Meanwhile, to increase hotel and restaurant tax strategy that includes improving human resources, system improvements and improvements in determining the hotel and restaurant tax revenue targets.

Keywords: Hotel, restaurant, tax, effectiveness.

Copyright @ 2019: This is an open-access article distributed under the terms of the Creative Commons Attribution license which permits unrestricted use, distribution, and reproduction in any medium for non-commercial use (NonCommercial, or CC-BY-NC) provided the original author and source are credited.

\section{INTRODUCTION}

In an effort to increase regional financial independence in Indonesia, the central government has sought to encourage each region at both the provincial and district/city levels to be able to increase their income from the potential that exists and is owned by each region.

To support the government's efforts, in order to hold good regional household affairs, strategic sources of regional income are needed, including regional income derived from local tax collection. As one component of Local Revenue (PAD), local taxes have a very good prospect to be developed. Therefore local taxes must be managed professionally and transparently in the context of optimization and efforts to increase their contribution to Local Revenue (PAD). As one of the strategic sources of local revenue, the collection of regional taxes must be carried out regularly and regularly in order to carry out increased regional development. This is intended so that regional revenues obtained from this tax levy can reach the set targets.

The potential source of regional revenue for Regional Original Revenue in the Tasikmalaya City is Restaurant Tax and Hotel Tax, this is because the number of restaurants and hotels has increased every year. Increasing the number of restaurants and hotels in Tasikmalaya City is a positive thing for an increase in the original income of Tasikmalaya City area. The more restaurants and hotels, the greater the income to increase local revenue.

Table-1: Target and Realization of Hotel and Restaurant Taxes in the City of Tasikmalaya in 2015 -2017 (IDR)

\begin{tabular}{|l|l|c|c|c|c|c|c|}
\hline \multirow{2}{*}{ No } & \multirow{2}{*}{ Jenis Pajak } & \multicolumn{2}{|c|}{$\mathbf{2 0 1 5}$} & \multicolumn{2}{c|}{$\mathbf{2 0 1 6}$} & \multicolumn{2}{c|}{$\mathbf{2 0 1 7}$} \\
\cline { 3 - 8 } & & Target & Realization & Target & Realization & Target & Realization \\
\hline 1 & Hotel & 2.610 .000 .000 & 2.294 .530 .818 & 2.610 .000 .000 & 3.083 .761 .801 & 3.130 .000 .000 & 3.341 .482 .725 \\
\hline 2 & Restaurant & 8.200 .000 .000 & 10.015 .330 .031 & 11.000 .000 .000 & 12.541 .335 .169 & 13.621 .000 .000 & 15.141 .302 .075 \\
\hline
\end{tabular}


Based on the table above, the realization of the Hotel Tax revenue in Tasikmalaya City in 2015 and 2016 did not meet the set targets, but in 2017 the Hotel Tax revenue has increased, while for the restaurant tax shows an increase every year. This shows that any increase or decrease in Hotel Tax and Restaurant Tax will be followed by an increase or decrease in PAD, because Hotel Tax and Restaurant Tax is a source of PAD in Tasikmalaya City. However, the fact that the Hotel Tax and Restaurant Tax is not managed properly, as shown in Table- 1 above shows that the realization that occurred was greater than the target set by the Regional Government of Tasikmalaya City. This is because the determination of the target is only always based on the revenue of previous years so that it allows the target set can always be achieved by the realization of greater hotel and restaurant tax revenue. This situation indicates that Hotel Tax and Restaurant Tax have not been optimally explored in its implementation. Responding to the aforementioned problems, the regional revenue department must re-collect data on the tax potential, because it is possible from the registered taxpayer to no longer conduct business activities. Apart from that, the increase in Hotel Tax and Restaurant Tax from year to year which is calculated from the realization of the amount of revenue cannot be used as a measure of the success of tax collection that has been done by the City Government of Tasikmalaya. One measure of the success of hotel and restaurant tax collection is to calculate the effectiveness of hotel tax collection. Based on the problems mentioned above, the researcher is interested in the effectiveness and strategy of increasing Hotel and Restaurant Taxes in Tasikmalaya City.

\section{RESEARCH PURPOSES}

- To calculate the effectiveness of Hotel Tax and Restaurant Tax

- To determine strategies in increasing hotel tax and restaurant tax revenue

\section{THEORITICAL REVIEW}

Regional Original Income is one source of revenue that must always be continuously spurred in its growth. In this regional autonomy, the independence of the regional government is highly demanded in financing regional development and service to the community. Article 6 of Law No. 33 of 2004 explains that the sources of Original Local Revenues consist of:

- Local Taxes,

- Regional Retribution,

- The results of the management of separated regional assets,

- $\quad$ Other valid Local Original Revenue (PAD).

Regional Taxes are compulsory contributions made by individuals or entities to regions without balanced direct benefits that can be imposed based on the applicable laws and regulations, which are used to finance the implementation of regional government and regional development. Local Tax according to the Law of the Republic of Indonesia Number 28 Year 2009 which is the latest amendment regarding Regional Tax and Regional Retribution, is divided into two regional taxes, namely:

- Provincial Tax includes 5 (five) types of Tax, namely; Motorized Vehicle Tax, Motorized Vehicle Transfer Fee, Fuel Tax, Surface Water Tax, and Cigarette Tax.

- Regency or City Tax includes 11 Types of Taxes, namely; Hotel Taxes, Restaurant Taxes, Entertainment Taxes, Advertisement Taxes, Street Lighting Taxes, Nonmetallic and Rock Mineral Taxes, Parking Taxes, Groundwater Taxes, Swallow Bird Nest Taxes, Rural and Urban Land and Building Taxes, and Land and Land Acquisition Fees Building.

Regional levies hereinafter referred to as levies, are regional levies as payments for services or the granting of certain licenses specifically provided and/or granted by the regional government.

The effectiveness of tax collection illustrates how the performance of a government, meaning how much the realization of hotel taxes and restaurant taxes that have been successfully achieved based on the target or the actual target must be achieved in a certain period. The amount of hotel tax and restaurant tax that can be collected by an area will certainly affect the amount of Local Original Revenue (PAD).

Empirically, hotel tax and restaurant tax greatly affect the region's original income [2, 3, 4, 10, $13,14,23]$, this implies that hotel tax contributions and restaurant taxes are very significant sources of development in a region. Besides that, the level of hotel tax effectiveness and categorized restoring is very effective [5-9, 11, 12, 15, 17-21, 24], meaning that each region has been serious in collecting taxes hotel and restaurant from taxpayers. However, on the other hand, although seen from the level of effectiveness it is included in the criteria of very effective, but this has not shown a high level of optimization, this can be seen from the contribution of hotel and restaurant tax which is still low [16, 22]. This means that these achievements are obtained without regard to the actual tax potential or tax intensification and extensification is still low.

\section{RESEARCH METHODS}

The object of this research is hotel and restaurant tax. The research method used in this study is a survey method, which is a method by visiting respondents directly to the research location. The population of this research is 341 taxpayers of hotels and restaurants in Tasikmalaya City, namely: Hotel Taxes of 40 taxpayers and Restaurants of 301 taxpayers. 
Apip Supriadi; Saudi J Bus Manag Stud, Sep 2019; 4(9): 729-735

Of the 341 taxpayers then a minimum sample was determined, using the Slovin formula as follows:

$$
n=\frac{N}{1+N e^{2}}
$$

From the above notation, $\mathrm{n}$ is the minimum number of samples, the value of $\mathrm{N}$ is the population while the value of e is the error margin. Departing from the idea of the error margin, it is possible that the creator of this formula provides the opportunity for researchers to determine the minimum sample size based on the error rate or margin of error.

Based on the calculation results of the Slovin formula the minimum sample results obtained for hotels and restaurants are:

Table-2: Total Population dan Sample

\begin{tabular}{|l|c|c|}
\hline Tax Type & Population & Sample \\
\hline Hotel & 40 & 28 \\
\hline Restaurant & 301 & 75 \\
\hline Total & 341 & 103 \\
\hline
\end{tabular}

Sumber: BPPRD Kota Tasikmalaya, 2018
Then from 103 minimum samples, in determining respondents using simple random sampling. Data collection in this study was carried out by Documentation, which is obtaining data by visiting relevant agencies to obtain preliminary data, and interviewing, namely obtaining data through questionnaires. The analytical tool used is effectiveness analysis with the formula formulation as follows:

To calculate the effectiveness of local taxes, use the following formula:

$$
\text { Effectiveness }=\frac{\text { Realization }}{\text { Target }} \times 100
$$

\section{RESULT}

Effectiveness is used to measure the relationship between the results of the realization of a tax levy with the goals or targets that have been set. Effectiveness is the relationship between outputs with goals or objectives that must be achieved. It is said to be effective if the activity process reaches the specified goals and objectives, then the work process of an organizational unit is effective. To provide an overview of the magnitude of the value of hotel and restaurant tax effectiveness can be seen in the following table.

\begin{tabular}{|c|c|c|c|c|}
\hline Year & $\begin{array}{l}\text { Target } \\
\text { IDR }\end{array}$ & $\begin{array}{l}\text { Realization } \\
\text { IDR }\end{array}$ & $\begin{array}{c}\text { Efektiveness } \\
(\%)\end{array}$ & Noted \\
\hline 2008 & $369,371,000$ & $458,826,871$ & 124 & Very Effective \\
\hline 2009 & $443,687,000$ & $514,645,163$ & 116 & Very Effective \\
\hline 2010 & $470,692,000$ & $575,636,025$ & 122 & Very Effective \\
\hline 2011 & $656,155,000$ & $828,613,484$ & 126 & Very Effective \\
\hline 2012 & $1,152,973,000$ & $1,619,022,149$ & 140 & Very Effective \\
\hline 2013 & $1,426,500,000$ & $1,944,599,272$ & 136 & Very Effective \\
\hline 2014 & $1,652,441,000$ & $2,236,970,016$ & 135 & Very Effective \\
\hline 2015 & $2,610,000,000$ & $2,294,530,818$ & 88 & Effective Enough \\
\hline 2016 & $2,610,000,000$ & $3,083,761,801$ & 118 & Very Effective \\
\hline 2017 & $3,130,000,000$ & $3,341,482,725$ & 107 & Very Effective \\
\hline 2018 & $4,580,000,000$ & $4,646,715,572$ & 101 & Very Effective \\
\hline \multicolumn{3}{|c|}{ Rata-rata } & 120 & Very effective \\
\hline
\end{tabular}

Table-3: Effectiveness of Hotel Taxes in the City of Tasikmalaya Year 2008 - 2018

Sumber: BPPRD Kota Tasikmalaya

In Table-3 the average hotel tax effectiveness in the Tasikmalaya City is categorized very effective (> $100 \%$ ), meaning that the local government of Tasikmalaya City in this case the Regional Tax and Retribution Management Agency (BPPRD) of Tasikmalaya City has been optimal in collecting hotel taxes from taxpayers.
When viewed from the effectiveness figures per year shows fluctuating values, with the highest effectiveness value in 2012 and the lowest effectiveness value occurred in 2015. To provide an overview of the development of the value of hotel tax 


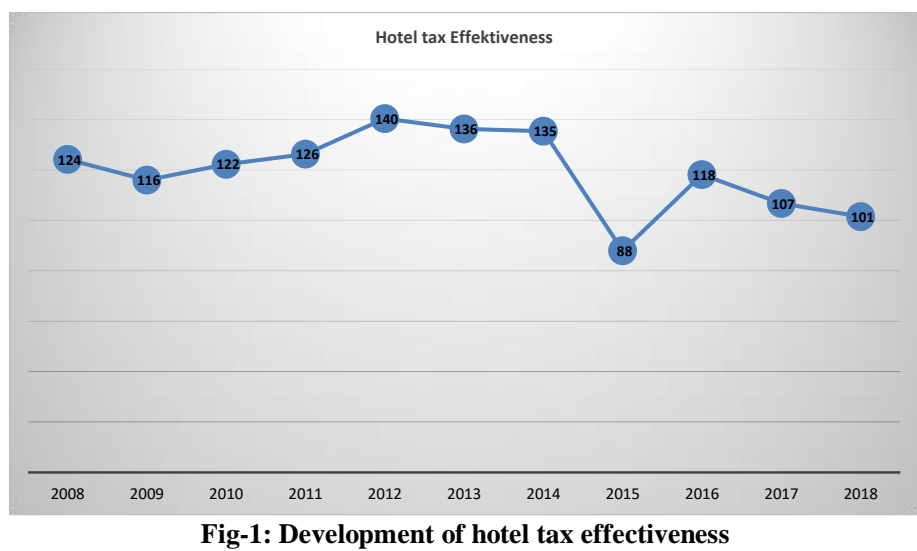

Next, by calculating the restaurant tax multiplied by 100 , you will get the value of restaurant realization divided by the restaurant tax target tax effectiveness as shown in the table below.

Table-4: Effectiveness of Restaurant Taxes in the City of Tasikmalaya Year 2008 - 2018

\begin{tabular}{|c|c|c|c|c|}
\hline Year & $\begin{array}{c}\text { Target } \\
\text { IDR }\end{array}$ & $\begin{array}{l}\text { Realization } \\
\text { IDR }\end{array}$ & Efektiveness $\quad(\%)$ & Noted \\
\hline 2008 & $1,388,148,000$ & $1,970,774,789$ & 142 & Very Effective \\
\hline 2009 & $1,739,278,000$ & $2,189,006,764$ & 126 & Very Effective \\
\hline 2010 & $3,260,602,000$ & $3,363,697,539$ & 103 & Very Effective \\
\hline 2011 & $3,624,416,000$ & $4,021,405,781$ & 111 & Very Effective \\
\hline 2012 & $4,197,860,000$ & $5,289,379,766$ & 126 & Very Effective \\
\hline 2013 & $4,644,000,000$ & $7,035,179,609$ & 151 & Very Effective \\
\hline 2014 & $5,233,940,000$ & $8,350,424,541$ & 160 & Very Effective \\
\hline 2015 & $8,200,000,000$ & $10,015,330,031$ & 122 & Very Effective \\
\hline 2016 & $11,000,000,000$ & $12,541,335,169$ & 114 & Very Effective \\
\hline 2017 & $13,621,000,000$ & $15,141,302,075$ & 111 & Very Effective \\
\hline 2018 & $17,932,000,000$ & $19,142,548,890$ & 107 & Very Effective \\
\hline \multicolumn{3}{|c|}{ Rata-rata } & 125 & Very effective \\
\hline
\end{tabular}

Source: BPPRD Kota Tasikmalaya

Taking into account the results of data processing in Table-4, the average value of the effectiveness of tax returns for 2008 - 2018 obtained is very effective. This explains that the Tasikmalaya City BPPRD has tried optimally in collecting restaurant tax from taxpayers.

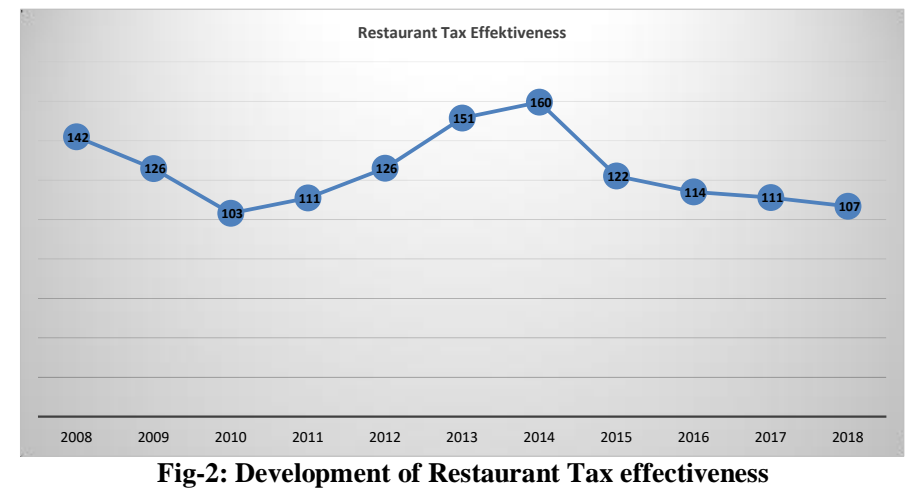

The development of restaurant tax effectiveness value as shown in figure 2, the behavior is the same as hotel tax, the value of restaurant tax effectiveness also shows a fluctuating amount each year. The highest value of tax effectiveness occurred in 2014 which amounted to $160 \%$ and the lowest value of effectiveness occurred in 2010 with a value of $103 \%$.
Hotel and Restaurant Tax Revenue Improvement Strategies

Before determining the strategy of increasing hotel and restaurant tax revenue, one must first know the internal environment (strengths, weaknesses), and also the external environment (opportunities and threats) known as SWOT analysis. The next step in determining the strategy is to enter it into the matrix 
Table-5: SWOT Matrix

\begin{tabular}{|c|c|c|}
\hline External Factors & $\begin{array}{l}\text { Strenght } \\
\text { 1. The availability of Regional Regulation of } \\
\text { Tasikmalaya City that guarantees and } \\
\text { regulates various hotel and restaurant tax } \\
\text { collection activities } \\
\text { 2. Support and roles from various offices and } \\
\text { institutions in the Tasikmalaya City } \\
\text { 3. Availability of adequate human resources in } \\
\text { hotel and restaurant tax collection } \\
\text { 4. Potential of various tourism attractions in the } \\
\text { Tasikmalaya City } \\
\text { 5. Potential of hotel accommodation and } \\
\text { restaurant accommodation availability in the } \\
\text { Tasikmalaya City } \\
\text { 6. Tasikmalaya City economic growth has } \\
\text { increased from year to year }\end{array}$ & $\begin{array}{l}\text { Weakness } \\
\text { 1. System and procedure for } \\
\text { collecting hotel and restaurant } \\
\text { tax in Tasikmalaya City is not } \\
\text { yet optimal } \\
\text { 2. There is still a lack of } \\
\text { professional staff in the } \\
\text { taxation field } \\
\text { 3. Traffic conditions in the } \\
\text { Tasikmalaya City that reduce } \\
\text { the interest of tourists to visit or } \\
\text { stay longer in the Tasikmalaya } \\
\text { City } \\
\text { 4. The budget allocation for } \\
\text { tourism from the Tasikmalaya } \\
\text { City Regional Budget is still } \\
\text { minimal }\end{array}$ \\
\hline $\begin{array}{l}\text { Opportunity } \\
\text { 1. Implementation of regional } \\
\text { autonomy in the Tasikmalaya } \\
\text { City } \\
\text { 2. Support of Law Number } 10 \text { Year } \\
2009 \text { concerning Tourism, which } \\
\text { enlarges the scope of the tourism } \\
\text { sector } \\
\text { 3. Tasikmalaya City Tourism in } \\
\text { terms of the scope of the National } \\
\text { and West Java Provinces is still a } \\
\text { tourist magnet for many domestic } \\
\text { and foreign tourists } \\
\text { 4. Opportunities from the existence } \\
\text { of the Wiradinata Airport } \\
\text { Cibeureum facilitate the arrival of } \\
\text { tourists to the Tasikmalaya City } \\
\text { 5. The number of tourist visits that } \\
\text { increase both local and foreign } \\
\text { with the various attractions in the } \\
\text { Tasikmalaya City }\end{array}$ & $\begin{array}{l}\text { Strategi SO } \\
\text { a) Increase the participation of taxpayers in the } \\
\text { implementation of hotel tax collection and } \\
\text { restaurant tax through counseling of } \\
\text { taxpayers } \\
\text { b) Increase tourism promotion and the presence } \\
\text { of hotels and restaurants in the Tasikmalaya } \\
\text { City by utilizing the development of } \\
\text { information systems with more effective } \\
\text { quality promotions } \\
\text { c) Utilizing the policy of regional autonomy as } \\
\text { widely as possible by using adequate human } \\
\text { resources and the tourism potential of the } \\
\text { Tasikmalaya City to attract domestic and } \\
\text { international tourists } \\
\text { d) Utilization of information technology in the } \\
\text { implementation of supervision and control of } \\
\text { hotel and restaurant tax collection }\end{array}$ & $\begin{array}{l}\text { Strategi WO } \\
\text { a) Ordering system and procedure } \\
\text { for collecting hotel and } \\
\text { restaurant tax in Tasikmalaya } \\
\text { City } \\
\text { b) Improving the quality of } \\
\text { inadequate human resources by } \\
\text { periodic training in the field of } \\
\text { taxation and updating of data, } \\
\text { to improve the ability and skills } \\
\text { so as to provide optimal service } \\
\text { c) Improve new strategies in } \\
\text { collecting hotel and restaurant } \\
\text { taxes } \\
\text { d) Increase tourism management } \\
\text { optimally and increase tourism } \\
\text { budget through assistance and } \\
\text { the Provincial Government } \\
\text { from the Central Government }\end{array}$ \\
\hline $\begin{array}{l}\text { Threat } \\
\text { 1. Tourism in other areas outside } \\
\text { the Tasikmalaya City which has } \\
\text { different characteristics, } \\
\text { completeness, and uniqueness. } \\
\text { 2. Issues of global terrorism, } \\
\text { security disturbances, and health } \\
\text { (outbreaks) other social disorders }\end{array}$ & $\begin{array}{l}\text { Strategi ST } \\
\text { a) Increasing the cooperation and coordination } \\
\text { of the Regional Government with various } \\
\text { relevant tourism entrepreneurs to develop } \\
\text { tourism that is safe, comfortable, sustainable } \\
\text { and sustainable } \\
\text { b) Improve the image and quality of tourism } \\
\text { and hotels and restaurants in the Tasikmalaya } \\
\text { City to be able to compete with other regions } \\
\text { that have developed } \\
\text { c) Organizing event events and souvenir craft } \\
\text { exchanges. Traditional art regularly } \\
\text { d) Directing development aimed at growing the } \\
\text { regional economy, increasing foreign } \\
\text { exchange, encouraging } \\
\text { development, expanding and provioning } \\
\text { employment and business opportunities that } \\
\text { can improve the welfare of the wider } \\
\text { community, and enrich and strengthen the } \\
\text { nation's culture }\end{array}$ & $\begin{array}{l}\text { Strategi WT } \\
\text { a) Facing the tendency of } \\
\text { competition among regions is } \\
\text { increasingly competitive } \\
\text { carried out by improving the } \\
\text { quality of human resources, } \\
\text { strengthening coordination, } \\
\text { optimizing awareness and law } \\
\text { enforcement } \\
\text { b) Increase awareness of various } \\
\text { things that can disturb order, } \\
\text { security and peace } \\
\text { c) Increase the tourism sector } \\
\text { budget allocation to be utilized } \\
\text { for developing the tourism } \\
\text { potential of the Tasikmalaya } \\
\text { City to attract domestic and } \\
\text { foreign tourists. } \\
\text { d) Opening opportunities to invest } \\
\text { in tourism development }\end{array}$ \\
\hline
\end{tabular}


Apip Supriadi; Saudi J Bus Manag Stud, Sep 2019; 4(9): 729-735

By considering the SWOT matrix in Table-5, the right strategy to increase local taxes from hotel taxes and restaurant taxes is the SO strategy, namely:

- Increase taxpayer participation in conducting hotel tax collection and restaurant tax through counseling of taxpayers.

- Increasing tourism promotion and the existence of hotels and restaurants in the Tasikmalaya City by utilizing the development of information systems with more effective quality promotions

- Utilizing the policy of regional autonomy to the greatest extent by using Adequate Human Resources and the tourism potential of the Tasikmalaya City to attract domestic and international tourists.

- Utilization of information technology in the implementation of supervision and control of hotel and restaurant tax collection

\section{CONCLUSION}

- The development of hotel and restaurant tax effectiveness values on average from 2008 2018, including the criteria are very effective

- In order for hotel and restaurant tax revenues to increase, a number of strategies need to be implemented in the following activities: socialization of the importance of local taxes, promotion of tourism potential in the Tasikmalaya City, dissemination of regional autonomy policies, and information technology training

\section{REFERENCE}

1. Abdul, H. (2001). Bunga Rampai Manajemen Keuangan Daerah. Yogyakarta: UPP AMP YKPN.

2. Rahmini, A. A. B. Y. S. (2016). Analisis Potensi Pajak Daerah Di Pemerintah Daerah Kabupaten Rokan Hulu. Cano Ekonomos, 5(2), 89-96.

3. Alisman, A. (2015). Analisis Faktor-Faktor yang Mempengaruhi Penerimaan Pajak Hotel di Kabupaten Aceh Barat. Jurnal Ekonomi dan Kebijakan Publik Indonesia, 2(1), 1-13.

4. Sulfiana, A. (2017). Pengaruh Penerimaan Pajak Hotel Dan Restoran, Retribusi Pelayanan Kesehatan, Dan Pengeluaran Pemerintah Daerah Terhadap Pad Kota Mojokerto. Equity, 3(3).

5. Sitompul, A., Syahnur, S., \& Ichsan, C. (2014). The Rule of Hotel and Restaurant taxes and Its Effect on banda Aceh's Local own Source Revenue. Aceh International Journal of Social Science, 3(1):45-57.

6. Mentari, D., \& Rahayu, S. (2015). Efektivitas Dan Kontribusi Penerimaan Pajak Hotel Dan Pajak Restoran Terhadap Pendapatan Asli Daerah Kota Bandung Tahun 2009-2013. eProceedings of Management, 2(2), 1770.

7. Ardhiansyah, D. (2014). Analisis Potensi Pajak Hotel Danpajak Restoran Dan Kontribusinya Terhadappendapatan Asli Daerah (Pad)(Studi
Kasus Pada Dinas Pendapatan Daerah Kota Batu Tahun 2011-2013). Jurnal Administrasi Bisnis, 14(1).

8. Dotulong, G. (2014). Analisis Potensi Penerimaan dan Efektivitas Pajak Restoran di Kabupaten Minahasa Utara. Jurnal Berkala Ilmiah Efisiensi, 14(2).

9. Syah, I., \& Rohman, A. (2014). Efektivitas dan Kontribusi Pajak Hotel terhadap Pendapatan Asli Daerah (Studi di Pemerintah Daerah Kota Semarang) (Doctoral dissertation, Fakultas Ekonomika dan Bisnis), 3(3).

10. Kadir, D. S. (2017). Efektivitas Pemungutan Dan Strategi Pengembangan Pajak Hotel Dan Restoran Di Kabupaten Kotabaru. Jurnal Bisnis Dan Pembangunan, 6(1).

11. Makalew, M. D., Nangoi, G. B., \& Lambey, R. (2018). Analisis Potensi Dan Efektivitas Penerimaan Pajak Restoran Di Kota Tomohon. Jurnal Riset Akuntansi Going Concern, 13(2): 57-67.

12. Virnawati, M., Hakim, D. B., \& Falatehan, A. F. (2017). Strategi Peningkatan Penerimaan Pajak Hotel di Kota Sukabumi. Matrik: Jurnal Manajemen, Strategi Bisnis dan Kewirausahaan, 11(2):136-150.

13. Sofyan, M. (2016). Sistem Pengendalian Intern Pengelolaan Pajak Restoran Dalam Meningkatkan Pendapatan Asli Daerah (PAD) Kota Bogor. Jurnal Eksekutif, 13(1).

14. Prayanti, N. L. P. A., Suwendra, I. W., \& Yudiaatmaja, F. (2014). Pengaruh Penerimaan Pajak Hotel, Pajak Restoran dan Retribusi Daerah Terhadap Pendapatan Asli Daerah Kabupaten Badung Tahun 2010-2013. Jurnal Jurusan Manajemen, 2(1).

15. Riastini, N. K. A., Sinarwati, N. K., Diatmika, I. P. G., SE, A., \& Si, M. (2017). Efektivitas Dan Kontribusi Pajak Hotel Dan Restoran Di Kintamani Terhadap Pendapatan Asli Daerah Kabupaten Bangli Tahun 2011-2015. JIMAT (Jurnal Ilmiah Mahasiswa Akuntansi) Undiksha, 8(2).

16. Azman, N., \& Farida, L. D. (2013). Optimalisasi Pemungutan Pajak Restoran. Jurnal Kebijakan Publik, 4(2):119-218.

17. Pratama, R. P., Saifi, M., \& ZA, Z. (2016) Efektivitas Penerimaan Pajak Restoran Dalam Meningkatkan Pendapatan Asli Daerah (Pad)(Studi Pada Dinas Pendapatan Asli Daerah Kabupaten Kediri). Jurnal Administrasi Bisnis, 30(1), 17-27.

18. Yuliandari, R., Chaidir, T., \& Mahmudi, H. (2017). The Analysis of Effectivity and Efficiency of Tax Collection from Hotels and Restaurants in Order to Increase the Original Regional Income (PAD) in Mataram. Jurnal Ekonomi dan Studi Pembangunan, 9(2), 251-256.

19. Toding, R. B. (2016). Analisis Potensi Dan Efektivitas Pemungutan Pajak Hotel Dalam 
Meningkatkan Pendapatan Asli Daerah Kota Palangka Raya. Jurnal EMBA: Jurnal Riset Ekonomi, Manajemen, Bisnis dan Akuntansi, 4(1): 214-222.

20. Pujiasih, R., \& Wardani, D. K. (2014). Analisis Potensi, Efektifitas dan Kontribusi Pajak Hotel Terhadap Pendapatan Asli Daerah Kabupaten Sleman. Jurnal Akuntansi, 2(2), 43-54.

21. Sahuddin, S., Fahmi, P., \& Anwar, S. (2018). Analisis Potensi Pajak Restoran di Kota Bengkulu. PARETO: Jurnal Ekonomi dan Kebijakan Publik, 1(1), 65-78.

22. Sunanto. (2015). Analisis Pengaruh Pajak Daerah Terhadap Pendapatan Asli Daerah Di Kabupaten
Musi Banyuasin. Jurnal Akuntansi Sekayu (Acsy), 1(1); 2407-2184.

23. Widodo, W. I., \& Guritno, B. (2017). Pengaruh Pajak Hotel, Pajak Restauran Dan Pajak Hiburan Terhadap Pendapatan Asli Daerah (Pad) Di Kota Yogyakarta. Jurnal Visi Manajemen, 2(2).

24. Sugiarto, Y., Danurdara, A. B., \& Rofi, N. (2015). Analisis Potensi Penerimaan Pajak Hotel di Kabupaten Pemalang Jawa Tengah. JURNAL BARISTA, 2(1).

25. Indonesia, R. (2004). Undang-Undang Republik Indonesia Nomor 33 Tahun 2004 Tentang Pemerintahan Daerah. Jakarta (ID): RI. 